\title{
ERYTHROCYTE PRESERVATION. VIII. METABOLIC DEGRADATION OF NUCLEOSIDES IN VITRO AND IN VIVO ${ }^{1}$
}

\author{
BY MARION HENNESSEY, CLEMENT A. FINCH, AND BEVERLY WESCOTT GABRIO
}

(From the Department of Medicine, University of Washington School of Medicine, Seattle, Washington and King County Blood Bank)

(Submitted for publication May 23, 1956; accepted November 29, 1956)

It has been shown previously that the addition of inosine to ACD preservative ${ }^{2}$ prolongs the effective period of in vitro storage of erythrocytes (1). Inosine is utilized by the red cell after a phosphorolytic cleavage to ribose-1-phosphate and hypoxanthine, mediated by a nucleoside phosphorylase $(2,3)$. Ribose-1-phosphate enters the "aerobic shunt pathway" of glucose metabolism after conversion to ribose-5-phosphate, and a subsequent effect is a generation of $\mathrm{ATP}^{3}$ and the resultant maintenance of the energy reserve of the red cell (4). Inasmuch as the red cell lacks the enzyme, xanthine oxidase (5), it is evident that the other cleavage product, hypoxanthine, is not metabolized further but remains in the red cell and the plasma during storage.

The present investigation is concerned with the rate of conversion of inosine to hypoxanthine by the red cells and the ratio of these substances in the plasma of blood stored in ACDI, as well as the in vivo metabolism of inosine after infusion. Related studies on the nucleosides, adenosine and guanosine, will be presented also.

\section{METHODS}

Human blood was collected in ACD, and the nucleoside, dissolved in 0.9 per cent $\mathrm{NaCl}$, was added with sterile precautions.

Inosine and adenosine were obtained from Schwarz Laboratories; hypoxanthine and guanosine from Nutritional Biochemicals Corporation.

Hemolysis during storage was determined by the measurement of plasma hemoglobin as the pyridine he-

1 This work was supported in part by research grants from the U. S. Atomic Energy Commission and the Office of the Surgeon General, Department of the Army.

2 Acid-citrate-dextrose, National Institutes of Health, Formula B.

3 The following abbreviations have been used: ATP $=$ adenosine triphosphate; $\mathrm{PCA}=$ perchloric acid; $\mathrm{ACDI}$, ACDA, ACDG, = acid-citrate-dextrose, inosine, adenosine or guanosine, respectively. mochromogen according to the method of Flink and Watson (6).

Paper chromatography (one-dimensional) on Whatman No. 1 filter paper was performed with the following solvent systems: isobutyric acid: concentrated ammonia: water $(66: 1: 33)$, $n$-butanol: water $(86: 14)$, and water adjusted to $\mathrm{pH} 10$ with $\mathrm{NH}_{4} \mathrm{OH}$, according to the methods described previously (1). After identification of the purine-containing compounds with the use of an ultraviolet light (Mineralite), the materials were eluted from the paper with water and measured spectrophotometrically. These substances were estimated also by quantitative densitometry ${ }^{4}$ of the paper chromatograms.

The hypoxanthine content of the plasma and red cells was determined enzymatically, using xanthine oxidase (7), except that the assays were performed on neutralized PCA filtrates of the various fractions.

Acid filtrates of plasma were prepared in the following way: $2 \mathrm{ml}$. of plasma were added to $2 \mathrm{ml}$. of cold 0.6 $\mathrm{N}$ PCA, mixed well, and centrifuged at $4^{\circ} \mathrm{C}$ for 5 minutes at $15,200 \times$ g.5 The precipitate was washed once with $2 \mathrm{ml}$. of cold $0.3 \mathrm{~N} \mathrm{PCA}$, and the centrifugation was. repeated. The supernatant fluid and the washing were combined and neutralized with cold 20 per cent $\mathrm{KOH}_{\text {r }}$ followed by centrifugation at $4^{\circ} \mathrm{C}$ for 10 minutes at $15,200 \times \mathrm{g}$. The $\mathrm{KClO}_{4}$ precipitate was washed once with $2 \mathrm{ml}$. of cold distilled water and centrifugation repeated. This second supernatant fluid and the washing were combined for analysis. Acid filtrates of the red cells were prepared in essentially the same way. Approximately $4 \mathrm{ml}$. of cells were washed twice with an equal volume of cold 0.9 per cent $\mathrm{NaCl}$ each time with centrifugation for 20 minutes at $1,700 \times$ g. ${ }^{8}$ The washings were discarded, since they contained only negligible amounts of ultraviolet absorbing materials.

A 50 per cent cell suspension was prepared with 0.9 per cent $\mathrm{NaCl}$. Hematocrit determinations were made on this cell suspension. One ml. of cell suspension was added to $3 \mathrm{ml}$. of cold $0.6 \mathrm{~N} \mathrm{PCA}$, and the neutralization of the acid filtrate proceeded as described above.

4 Photovolt densitometer, Model 301A, phototube B, filter 5265, wave-length $253 \mathrm{~m} \mu$.

5 Twelve thousand rpm; International Centrifuge Model PRI; high speed attachment; radius from bottom of tube equals $9.5 \mathrm{~cm}$.

6 Three thousand rpm; International Centrifuge Model PRI; rotor No. 269, radius from center of tube equals $17 \mathrm{~cm}$. 
Absorption spectra measurements in the region of 230 to $300 \mathrm{~m} \mu$ were obtained with the use of the Beckman DU spectrophotometer on the PCA filtrates of plasma or red cells. Since both hypoxanthine and inosine were present in the plasma of blood stored in ACDI or ACDA $(1,4,8)$, the relative amounts of each substance could not be estimated directly from light absorption measurements alone. However, after the amount of hypoxanthine had been determined by means of xanthine oxidase, it was possible from the light absorption data on the plasma filtrates, to correct the extinction values at $249 \mathrm{~m} \mu$ (peak light absorption of hypoxanthine, millimolar extinction coefficient $=10.5$ ) for hypoxanthine concentration. The readings were also corrected for the light absorption of appropriate control samples, i.e., untreated with nucleoside. Thus a value was obtained which was due to inosine. Approximately 400 -fold dilutions were made of all samples for spectrophotometric measurement, and the light absorption of the control samples during storage was less than 2 per cent of the nucleoside-treated samples.

Uric acid was determined on plasma and urine by the uricase method of Dubbs, Davis, and Adams (9).

\section{RESULTS AND DISCUSSION}

\section{Storage of blood in ACDI}

The ratio of hypoxanthine to inosine during the storage of blood in ACDI at $4^{\circ} \mathrm{C}$ was determined in two experiments. In the first investigation, only the ratio in the plasma was estimated, while the second study involved the ratio of the two compounds in both plasma and red cell fractions.

Experiment 1. Human blood was collected in $\mathrm{ACD}$ and divided into two $100-\mathrm{ml}$. aliquots. After 24 hours of storage at $4^{\circ} \mathrm{C}, 20 \mathrm{ml}$. of 0.9 per cent $\mathrm{NaCl}$ were added to one aliquot, and $20 \mathrm{ml}$. of inosine solution in 0.9 per cent $\mathrm{NaCl}$ (1300, $\mu$ moles, i.e., 3,000 , $\mu$ moles per $100 \mathrm{ml}$. red cells) were added to the other. Analyses were performed subsequently on days $4,9,15,23,37$, and 57.

There is progressive uptake of inosine by the red cell ( $c f$. ., Table I), so that by 57 days there are only $14 \mu$ moles of inosine remaining in the plasma, while $1,286 \mu$ moles have been taken up by the cells. Of this amount absorbed, $440 \mu$ moles have returned to the plasma as hypoxanthine, leaving $846 \mu$ moles inside the cells as inosine and hypoxanthine. Paper chromatographic experiments revealed that only two ultraviolet absorbing materials, i.e., hypoxanthine and inosine, were present in the plasma fractions throughout storage. Furthermore, quantitative densitometry of the chromatograms confirmed the ratios of hypoxanthine to inosine given in Table I. The enzyme responsible for the phosphorolytic cleavage of the nucleoside, nucleoside phosphorylase, has been shown previously to be in the soluble portion of the red cells ( 3 ).

After phosphorolytic cleavage of inosine, the ribose moiety is metabolized further by the red cell during storage (4), while the nitrogenous base, hypoxanthine, remains unchanged. As the time of storage progresses, hypoxanthine diffuses from the red cell into the plasma fraction in increasing amounts.

Experiment 2. Human blood was collected in ACD and divided into two aliquots: 1) $100 \mathrm{ml}$. blood $+20 \mathrm{ml}$. saline ; 2) $100 \mathrm{ml}$. blood $+20 \mathrm{ml}$. inosine solution (1,272 $\mu$ moles, i.e., 3,500 $\mu$ moles per $100 \mathrm{ml}$. red cells). Both aliquots were stored at $4^{\circ} \mathrm{C}$ for 36 days. The data are reported in Table II. After 36 days of storage there were $742 \mu$ moles of hypoxanthine and $361 \mu$ moles of inosine distributed between the plasma and red cell fractions, or a total of $1,103 \mu$ moles of material. This leaves $169 \mu$ moles (13 per cent of the original amount of inosine) unaccounted for. This loss of material is unexplained, at present, although paper chromatography indicated the presence of an unknown compound capable of absorbing ultraviolet light in the nucleoside-treated sample which was not present in the control erythrocytes.

TABLE I

Plasma hypoxanthine:inosine ratio of blood stored in $A C D I$

\begin{tabular}{|c|c|c|c|c|c|}
\hline \multirow[b]{2}{*}{$\begin{array}{c}\text { m } \\
\text { 'Days'. } \\
\text { storage }\end{array}$} & \multicolumn{3}{|c|}{ Plasma fraction* $\uparrow$} & \multirow[b]{2}{*}{ 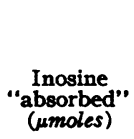 } & \multirow[b]{2}{*}{$\begin{array}{c}\% \\
\text { Inosine } \\
\text { "absorbed" }\end{array}$} \\
\hline & $\begin{array}{l}\text { Inosine } \\
\text { (umoles) }\end{array}$ & $\begin{array}{c}\text { Hypo- } \\
\text { ranthine } \\
\text { (umoles) }\end{array}$ & $\begin{array}{l}\text { Hypo- } \\
\text { xanthine: } \\
\text { Inosine } \\
\text { ratio }\end{array}$ & & \\
\hline $\begin{array}{r}1 \\
4 \\
9 \\
15 \\
23 \\
37 \\
57\end{array}$ & $\begin{array}{c}1,300 \ddagger \\
928 \\
709 \\
538 \\
277 \\
150 \\
14\end{array}$ & $\begin{array}{l}143 \\
241 \\
296 \\
298 \\
376 \\
440\end{array}$ & $\begin{array}{r}0.15 \\
0.34 \\
0.55 \\
1.08 \\
2.51 \\
31.40\end{array}$ & $\begin{array}{r}372 \\
591 \\
762 \\
1,023 \\
1,150 \\
1,286\end{array}$ & $\begin{array}{l}29 \\
46 \\
59 \\
79 \\
89 \\
99\end{array}$ \\
\hline
\end{tabular}

* The plasma fraction represents the plasma, ACD, and the saline diluent for inosine added to the $100-\mathrm{ml}$. aliquot of blood (20-ml. inosine solution).

$\dagger$ All values have been corrected for the values of the control sample $(100 \mathrm{ml}$. aliquot of blood stored in ACD +20 ml. saline).

$\ddagger$ Thirteen hundred $\mu$ moles inosine added after 24 hours' storage. 
TABLE II

The relationship of hypoxanthine to inosine in plasma and red cells of blood stored in $A C D I$

Human blood was stored for 36 days in ACD (100 ml. blood $+20 \mathrm{ml}$. saline $)$ and in ACDI $(100 \mathrm{ml}$. blood +20 ml. inosine $=1272 \mu$ moles).

\begin{tabular}{lccc}
\hline \hline & \multicolumn{3}{c}{36 days stored (ACDI) } \\
\cline { 2 - 4 } & $\begin{array}{l}\mu \text { moles } \\
\text { Is* }\end{array}$ & $\begin{array}{c}\mu \text { moles } \\
\mathrm{Hx}^{*}\end{array}$ & $\begin{array}{c}\mathrm{Hx} \text { ratio } \\
\text { ratio }\end{array}$ \\
\hline Plasma fraction & 330 & 529 & 1.6 \\
RBC fraction & 31 & 213 & 6.9 \\
Total $\dagger$ & 361 & 742 & \\
\hline
\end{tabular}

* $\mathrm{Hx}=$ Hypoxanthine; Is = Inosine.

$\dagger$ Total recovery of $1,103 \mu$ moles $(361+742)$ is $87 \%$ of the original amount. All values are corrected for those of the control (ACD).

Calculations of the concentration of hypoxanthine in either plasma or red cells revealed that at 36 days of storage there was an equilibrium established (approximately $6 \mu$ moles hypoxanthine per ml.).

\section{Storage of blood in $A C D A$ and $A C D G$}

Similar experiments were carried out on blood stored in ACD with the addition of either 1,200 $\mu$ moles of adenosine or $1,300 \mu$ moles of guanosine under conditions identical to those described in Experiment 1.

In the study of blood stored in ACDA it was apparent from paper chromatographic analysis that, after 4 days of storage, there was no adenosine in the plasma fraction, and that inosine and hypoxanthine were the only ultraviolet absorbing substances present. In the plasma filtrates throughout storage (i.e., from 4 to 57 days) maximum light absorption occurred between 247 and $249 \mathrm{~m} \mu$. By direct measurement, the amounts and ratios of hypoxanthine and inosine were similar to those described for blood stored in ACDI, e.g., on days $4,9,15,23,37$, and 57 , the ratios of hypoxanthine to inosine in the plasma were 0.09 , $0.23,0.76,1.60,2.20$, and 35.3 , respectively. Thus, it appears as if storage of blood with adenosine is quite similar to storage with inosine except that the enzymatic conversion of adenosine to inosine via the adenosine deaminase (10) results in the liberation of ammonia which accumulates in the blood during storage (1). This conversion of adenosine to inosine is complete after
TABLE III

Hemolysis during storage of blood in $A C D I$ and $A C D A$

\begin{tabular}{crcc}
\hline \hline \multirow{2}{*}{$\begin{array}{c}\text { Days' } \\
\text { storage }\end{array}$} & \multicolumn{3}{c}{ Mg. hemoglobin per 100 ml. plasma fraction } \\
\cline { 2 - 4 } & Control* & ACDI* & ACDA* \\
\hline 4 & 29 & 14 & 15 \\
9 & 37 & 24 & 35 \\
15 & 59 & 34 & 42 \\
23 & 121 & 56 & 61 \\
37 & 292 & 102 & 107 \\
57 & 1,296 & 362 & 329 \\
\hline
\end{tabular}

* Control $(A C D)=100 \mathrm{ml}$. blood $+20 \mathrm{ml}$. saline, ACDI $=100 \mathrm{ml}$. blood $+20 \mathrm{ml}$. inosine $(1,300 \mu \mathrm{moles})$, ACDA $=100 \mathrm{ml}$. blood $+20 \mathrm{ml}$. adenosine $(1,200 \mu \mathrm{moles})$.

one-hour incubation of stored cells with adenosine (1). The above evidence is confirmatory to previous work from this laboratory $(4,11)$ and in accordance with the observations of Rubinstein, Kashket, and Denstedt (8).

The degree of hemolysis in blood stored in ACDI and ACDA is compared in Table III. The similarity is apparent, inasmuch as the presence of either nucleoside suppresses hemolysis during storage, although all values are relatively high due to the fact that at each time of sampling, the blood was agitated by thorough mixing.

Analyses of plasma removed from blood stored in ACDG show that guanine is the purine base liberated from guanosine as a result of phosphorolytic cleavage. Guanine is not degraded further during in vitro storage. Studies employing paper chromatography reveal that the increasing concentration of plasma guanine during storage is of the same order of magnitude as the amount of plasma hypoxanthine found in blood stored in ACDI. Neither adenosine nor inosine were detected in blood stored in ACDG.

\section{The fate of hypoxanthine and guanine after infu- sion of their ribosides}

It was of interest to investigate the metabolism of purine moieties of inosine and guanosine after intravenous administration of these purine nucleosides into human recipients.

Two experiments were performed in which normal subjects received about 7,000 $\mu$ moles of inosine intravenously in a $500-\mathrm{ml}$. saline infusion. This amount of inosine is equivalent to that required for the preservation of one unit of blood. 
TABLE IV

Serum uric acid after inosine infusion

Experiment 1. Normal male subject $(99 \mathrm{Kg}$.) received intravenously $6,960 \mu$ moles inosine over a period of $1.5 \mathrm{hr}$.

Experiment 2. Normal male subject $(103 \mathrm{Kg}$.) received intravenously $7,470 \mu$ moles inosine over a period of $1.25 \mathrm{hr}$.

\begin{tabular}{cc}
\hline $\begin{array}{c}\text { Time after end } \\
\text { of infusion }\end{array}$ & $\begin{array}{c}\text { Mg. uric acid per } \\
\text { 100 ml. serum }\end{array}$ \\
\hline Expt. 1 & \\
0 & 6.1 \\
5 min. & 8.8 \\
45 min. & 9.8 \\
$3 \mathrm{hr}$. & 7.4 \\
$5 \mathrm{hr}$. & 8.4 \\
& \\
Expt. 2 & \\
0 & 6.1 \\
$8 \mathrm{~min}$. & 11.5 \\
$1 \mathrm{hr}$. & 10.0 \\
$3 \mathrm{hr}$. & 8.9 \\
$5 \mathrm{hr}$. & 8.7 \\
$8 \mathrm{hr}$. & 8.5 \\
$27 \mathrm{hr}$. & 6.1 \\
\hline
\end{tabular}

Levels of uric acid in serum and urine were determined at various time intervals after the infusion. A transient rise in serum uric acid was produced soon after the infusion, but the value returned to normal in about 24 hours (Table IV).

Uric acid excretion was measured over a period of about 2 days after the infusion and was compared to the normal excretion levels of the subjects. Approximately 32 per cent of the dose of inosine was excreted as uric acid during a period of 24 hours after the infusion (Table V). Subsequent sampling indicated that an additional 10 per cent of the dose was excreted over the next 12 hours at which time the uric acid levels had returned to normal.

Although these experiments are preliminary in nature, it is probable that the series of events which occur in vivo after the infusion of inosine are those shown in equation (1).

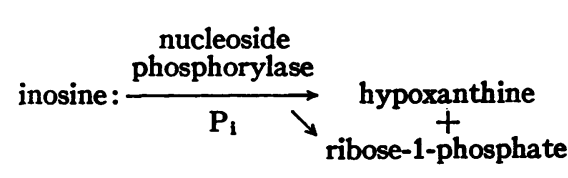

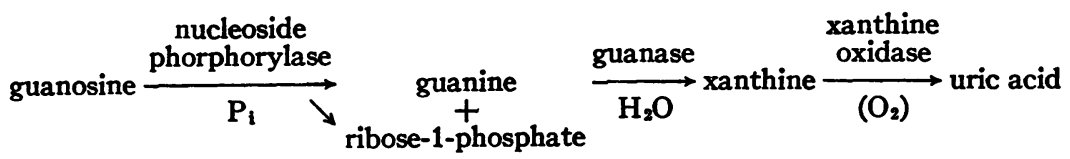

TABLE V

Uric acid excretion after inosine infusion

Experimental conditions as in Table IV

\begin{tabular}{ccc}
\hline \hline & $\begin{array}{c}\text { Mmoles uric acid excre- } \\
\text { tion above normal } \\
\text { in 24-hour post } \\
\text { infusion period* }\end{array}$ & $\begin{array}{c}\text { \% dose of inosine } \\
\text { excreted as uric } \\
\text { acid in 24 hr. }\end{array}$ \\
\hline Expt. 1 & 2,427 & 34.9 \\
Expt. 2 & 2,344 & 31.4
\end{tabular}

* Normal urinary uric acid was established in the subjects as $3,993 \mu$ moles per 24 hours.

Guanosine $(7,060 \mu$ moles $)$ was administered similarly to a patient with leucopenic leukemia, and the data recorded in Table VI indicate that the metabolic end product of the purine base in this case was the same, i.e., uric acid. It is probable that the phosphorolysis and oxidation proceed according to equation (2).

Previous studies on the subcutaneous injection of guanosine have demonstrated increments of uric acid excretion in the urine (12). While neither these previous results nor the data presented in this communication permit any conclusions as to the urinary yield of converted nucleoside, they would appear to be within the range observed after the intravenous administration of uric acid alone, i.e., about 60 per cent (13).

\section{TABLE VI}

\section{Serum uric acid after guanosine infusion}

Patient $(58 \mathrm{Kg}$.) with leucopenic leukemia received intravenously $7,060 \mu$ moles guanosine over a period of one hour.

\begin{tabular}{cc}
\hline $\begin{array}{c}\text { Time after end } \\
\text { of infusion }\end{array}$ & $\begin{array}{c}\text { Mg. uric acid per } \\
100 \mathrm{ml} \text {. serum }\end{array}$ \\
\hline 0 & 4.4 \\
$10 \mathrm{~min}$. & 10.9 \\
$2 \mathrm{hr}$. & 11.9 \\
$3 \mathrm{hr}$. & 12.0 \\
$5 \mathrm{hr}$. & 13.3 \\
$12 \mathrm{hr}$. & 10.8 \\
$20 \mathrm{hr}$. & 6.5 \\
\hline
\end{tabular}

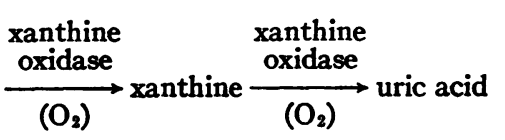

$$
\underset{\mathrm{H}_{2} \mathrm{O}}{\stackrel{\text { guanase }}{\longrightarrow}} \text { xanthine } \underset{\left(\mathrm{O}_{2}\right)}{\stackrel{\substack{\text { xanthine } \\ \text { oxidase }}}{\longrightarrow} \text { uric acid }}
$$


SUMMARY

After being taken up by erythrocytes, inosine undergoes enzymatic phosphorolysis to yield ribose-1-phosphate and hypoxanthine. The hypoxanthine diffuses outward into the plasma during storage until an equilibrium is reached with that inside the cells.

Adenosine is converted rapidly to inosine during storage and is utilized through the same metabolic pathway, with the resultant increasing concentration of hypoxanthine in the plasma. Guanosine is utilized similarly with the exception that guanine is the purine base which accumulates in the plasma.

The intravenous administration of inosine indicates that the hypoxanthine is oxidized further in vivo to uric acid. Likewise, guanosine infusion results in increased concentrations of uric acid in the blood serum.

\section{REFERENCES}

1. Gabrio, B. W., Donohue, D. M., Huennekens, F. M., and Finch, C. A., Erythrocyte preservation. VII. Acid-citrate-dextrose-inosine (ACDI) as a preservative for blood during storage at $4^{\circ} \mathrm{C}$. J. Clin. Invest., 1956, 35, 657.

2. Gabrio, B. W., and Huennekens, F. M., The role of nucleoside phosphorylase in erythrocyte preservation. Biochim. et Biophys. Acta, 1955, 18, 585.

3. Huennekens, F. M., Nurk, E. G., and Gabrio, B. W., Erythrocyte metabolism. I. Purine nucleoside phosphorylase. J. Biol. Chem., 1956, 221, 971.
4. Gabrio, B. W., Finch, C. A., and Huennekens, F. M., Erythrocyte preservation: A topic in molecular biochemistry. Blood, 1956, 11, 103.

5. Sandburg, A. A., Lee, G. R., Cartwright, G. E., and Wintrobe, M. M., Purine nucleoside phosphorylase activity of blood. I. Erythrocytes. J. Clin. Invest., 1955, 34, 1823.

6. Flink, E. B., and Watson, C. J., A method for the quantitative determination of hemoglobin and related heme pigments in feces, urine, and blood plasma. J. Biol. Chem., 1942, 146, 171.

7. Mackler, B., Mahler, H. R., and Green, D. E., Studies on metalloflavoproteins. I. Xanthine oxidase, a molybdoflavoprotein. J. Biol. Chem., 1954, 210, 149.

8. Rubinstein, D., Kashket, S., and Denstedt, O. F., Studies on the preservation of blood. IV. The influence of adenosine on the glycolytic activity of the erythrocyte during storage at $4^{\circ} \mathrm{C}$. Canad. J. Biochem. \& Physiol., 1956, 34, 61.

9. Dubbs, C. A., Davis, F. W., and Adams, W. S., Simple microdetermination of uric acid. J. Biol. Chem., 1956, 218, 497.

10. Schaedel, M. L., and Schlenk, F., Adenosine and adenosine deaminase. Texas Rep. Biol. \& Med., 1948, 6, 176.

11. Gabrio, B. W., and Huennekens, F. M., Nucleoside metabolism of stored erythrocyte. Federation Proc., 1955, 14, 217.

12. Thannhauser, S. J., and Bommes, A., Experimentelle Studien über den Nucleinstoff wechsel. II. Mitteilung. Stoffwechselversuche mit Adenosin und Guanosin. Ztschr. f. physiol. Chem., 1914, 91, 336.

13. Buzzard, J., Bishop, C., and Talbott, J. H., Recovery in humans of intravenously injected isotopic uric acid. J. Biol. Chem., 1952, 196, 179. 